Research Article

\title{
Bending Performance of Prestressed Continuous Glulam Beams
}

\author{
Nan Guo $\left(\mathbb{D},{ }^{1}\right.$ Mingtao Wu $\mathbb{D},{ }^{1}$ Ling Li $\mathbb{D},{ }^{1}$ Guodong Li $\left(\mathbb{D},{ }^{1}\right.$ and Yan Zhao $\mathbb{D}^{2}$ \\ ${ }^{1}$ College of Civil Engineering, Northeast Forestry University, Harbin 150040, China \\ ${ }^{2}$ School of Civil Engineering and Architecture, Wuyi University, Wuyishan 354300, China \\ Correspondence should be addressed to Ling Li; liling@nefu.edu.cn
}

Received 2 March 2021; Revised 14 May 2021; Accepted 12 June 2021; Published 28 June 2021

Academic Editor: Giovanni Garcea

Copyright (c) 2021 Nan Guo et al. This is an open access article distributed under the Creative Commons Attribution License, which permits unrestricted use, distribution, and reproduction in any medium, provided the original work is properly cited.

\begin{abstract}
The limited transferring moment capability of Glulam (glued laminated wood) joints results in insufficient joint stiffness. Therefore, most of the connections are hinged joints. Based on the previous studies, one novel end-connection device was proposed to form prestressed continuous Glulam beams. The prestressed beams were composed of prestressed low-relaxation steel bars, the deviator block, the anchorage device, and the novel end-connection apparatus. These prestressed steel bars were tensioned by the deviator block to exert prestress. Then, 18 prestressed continuous beams and two prestressed simply supported beams were subject to the bending tests to explore the impact of reinforcement ratio and prestress on the prestressed Glulam beams from aspects such as failure modes, bearing capacity, load-deflection relationship, and load-strain relationship. The results show that, given the same prestress level, compared with beams with a reinforcement ratio of $1.92 \%$, the bearing capacity of beams with a reinforcement ratio of $3.84 \%$ and $5.76 \%$ is increased by $20.3 \%-29.4 \%$ and $30.51 \%-36.36 \%$, respectively. Given the same reinforcement ratios, compared with beams without prestressing, the bearing capacity of beams with a prestressing force of $7 \mathrm{kN}$ and $14 \mathrm{kN}$ is increased by $2.39 \%-10.14 \%$ and $6.49 \%-13.26 \%$, respectively. In addition, compared with simply supported beams, the bearing capacity of continuous beams is increased by $40 \%$, and the deformation is reduced by $13 \%$. Therefore, as a novel prestressed beam, the bending performance of Glulam beams can be improved effectively.
\end{abstract}

\section{Introduction}

With carbon storage and environmentally friendly characteristics, timber has gotten more attention from all walks of life because of its excellent mechanical performance and renewability. Timber has been widely used as a construction material [1-3]. Meanwhile, timber structure has the merits of good thermal insulation performance, energy-saving, emission reduction, and safe and comfortable living; therefore, under the background of vigorously advocating green building, timber structure has gotten new development opportunities [4]. As an important structural material of modern timber structure, Glulam not only solves the drawbacks of traditional wood material in low lumber recovery and being difficult to process, but also, compared with traditional timber materials, has the advantages of fewer centralized defects, high strength, various cross section and component shapes, and reasonable stress distribution [5]. However, due to the limit of the size of the raw materials and processing techniques, the length of Glulam beams generally cannot meet the requirements of the continuous beams. Under the bending state, the failure always occurs on the tensile zone; thus, the compressive strength cannot be fully utilized [6]. In addition, most Glulam beams are simply supported beams, because the capability of traditional Glulam connections to transmit bending moment is relatively weak, which would result in insufficient joint stiffness. Therefore, many strengthening methods were proposed to improve timber structures capacity. As common reinforced materials, many types of reinforced polymers, steel plates, and steel bars are used to enhance the ductility and flexural capacity and reduce the deformation of Glulam beams. Investigations on the behavior of timber beams reinforced with those were studied [7-17]. Gribanov et al. [7] studied the different laminar polymer composites for wooden structures and suggested the corresponding design suggestions. CFRP (carbon fiber-reinforced polymer) bars were used to improve the flexural capacity and the stiffness of 
Glulam beams by Yang et al. [16]. Because of the CFRP bar, the failure mode was changed from brittle tension failure to ductile compression failure, and the flexural capacity got significant improvement. Nowak et al. [17] compared the capacities of timber beams pasted different steel plates and then gave design suggestions. Zhang et al. [8] presented an experimental investigation on PBSL (parallel bamboo strand lumber) beams reinforced with AFRP (aramid fiber-reinforced polymer). The cloth ratio was the only studied variable; then flexural capacity, stiffness, and the load-carrying capacity of the tested beams were evaluated. The results showed that bonding AFRP can increase the stiffness of PBSL beams. The ductility of the PBSL beams could be effectively enhanced by adopting the AFRP provision. Meanwhile, the NSM (near-surface mounted) technique has been applied to timber structures $[18,19]$. Jorge et al. [18] studied the bond between Glulam and NSM CFRP laminates; the local bond stress-slip relationship and failure modes were determined, and they found that the bond length was the main influence factor. Branco et al. [19] proposed that GFRP robs were mounted to double-span continuous Glulam slabs bottom to strengthen its capacity. The results indicated that bending capacity and deformation capacity could be improved significantly. The use of prestress for structural strengthening of timber structures was detailedly assessed, and then prestress was used to strengthen the mechanical properties of the Glulam beams [20-29]. Wei et al. [21] proposed a novel steel-reinforced PBSL beam in which steel bars or prestressed steel bars were embedded in bamboo-composite beams. The result showed that the ultimate bearing capacity of the reinforced beams increases with an increasing reinforcement ratio and prestress, but the influence of the prestress was inferior to that of the diameter of the reinforced bars. Yang et al. [26] investigated the bending performance of the external prestressed Glulam beams, and control stress for prestressing, the height of steel deviator, and cross-sectional shape of Glulam beams were studied variables. The results demonstrated that the ultimate loads and flexural stiffness of reinforced beams could get significant improvement, and the typical failure mode was the timber yield failure in compression zone for reinforced and prestressed Glulam beams. In addition, a series of finite element models were developed to predict all influential factors of the Glulam beams and verify some novel reinforcement methods by some researchers [30, 31].

Although these previous studies had investigated the unreinforced and reinforced Glulam beams, all of them were based on simply supported beams [8-31]. There is not any research on prestressed continuous beams. Therefore, based on prestressed simply supported Glulam beams proposed in previous studies $[28,29]$, a set of end-connection devices are invented in this study to form prestressed continuous Glulam beams. As a novel prestressed composite bending bearing member, the prestressed continuous Glulam beams have the advantages of prestressed simply supported Glulam beams and the improved joint stiffness. Through the endconnection device and the prestress, semirigid connections are achieved, which change the bending moment distribution to utilize the material with reduced deformation better.
Therefore, this study examines the behavior of a novel prestressed continuous Glulam beam with different reinforcement ratios and prestress levels. Moreover, based on experimental results, a detailed theoretical analysis is given.

\section{Materials and Methods}

2.1. Material. The raw timber material was spruced from Heilongjiang Province, China. The dried spruce plates were formed into a rectangular shape with phenolic adhesives and cured at a temperature of $25^{\circ} \mathrm{C}$. The grade of the timber was $I_{c}[32]$. Based on Chinese standards [32, 33] and the former study [34], compressive tests and tensile tests were carried out in the laboratory of Northeast Forestry University. According to compressive tests, the peak compressive strength $\left(f_{c \mu}\right)$ is $38.67 \mathrm{MPa}$, and the compressive elastic modulus is $8301.14 \mathrm{MPa}$, with the coefficients of variation of $4.63 \%$ and $6.14 \%$, parallel to the fibers, respectively. According to tensile tests, the peak tensile strength $\left(f_{t \mu}\right)$ is 81.32 $\mathrm{MPa}$, and the tensile elastic modulus is $9750.11 \mathrm{MPa}$, with the coefficients of variation of $6.42 \%$ and $6.18 \%$, parallel to the fibers, respectively. All steel specimens were lowrelaxation prestressed steel wires, the nominal yield strength of the steel bar is $1570 \mathrm{MPa}$, and its tensile strength and elastic modulus are $1640.51 \mathrm{MPa}$ and $1.92 \times 10^{5} \mathrm{MPa}$, with the coefficients of variation of $1.71 \%$ and $0.35 \%$.

2.2. Test Procedure. In this paper, the prestressed Glulam continuous beam was composed of Glulam, high-strength steel wires, and steel components (including prestressed control device, steel plate, and connection apparatus), as shown in Figures 1 and 2.

To study the bending performance of the prestressed continuous Glulam beams and compare them with prestressed simply supported Glulam beams, the test beams are divided into two groups, Group A and Group B. Figures 3-5 show, respectively, the schematic diagrams of the tested beams. Group A contained continuous beams, with the dimension of $6260 \mathrm{~mm} \times 80 \mathrm{~mm} \times 100 \mathrm{~mm}$ (length $\times$ width $\times$ height). All specimens were set with low-relaxation prestressed steel wires with $7 \mathrm{~mm}$ in diameter. The tests included working conditions, and there were a total of 18 test beams, two for each working condition. To study the impact of the number of prestressed steel bars and prestress levels on the bending performance of the continuous Glulam beams, Group A was subdivided into two subgroups (Group I and Group II). Group I was used to test the impact of reinforcement ratio on the bending performance of the beam, and the calculation formula for the reinforcement ratio is $\rho=A_{s} / b h(\%)$, where $A_{s}$ is the total area of the steel bars and $b$ and $h$ are, respectively, the width and height of the section of the beam. Group II was used to test the impact of prestress on the bending performance of the beam, and the basic details of the test beams are shown in Tables 1 and 2 .

To evaluate the advantages of continuous Glulam beams in failure mode, bearing capacity, and deformation, prestressed simply supported Glulam beams with a dimension of $3070 \mathrm{~mm} \times 80 \mathrm{~mm} \times 100 \mathrm{~mm} \quad$ (length $\times$ width $\times$ height) 


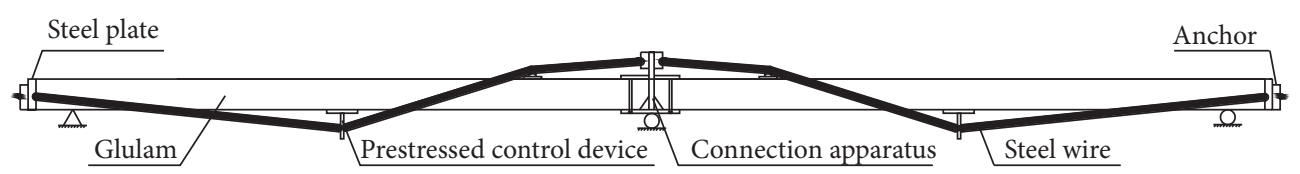

(a)

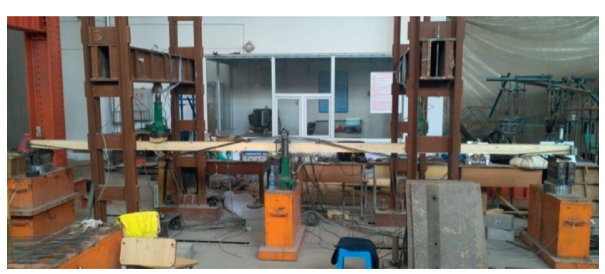

(b)

FIgURE 1: Prestressed Glulam continuous beam. (a) Details of the specimen. (b) Figure of the specimen.

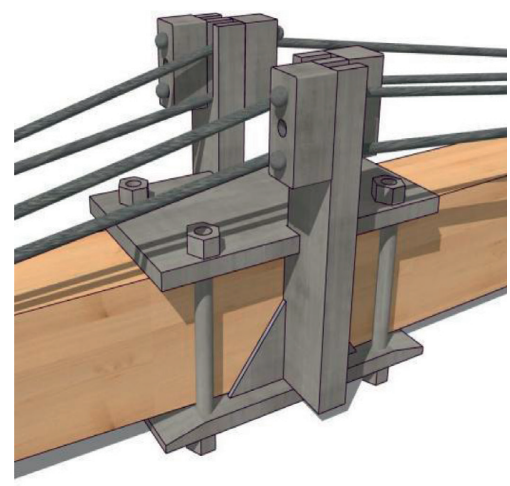

(a)

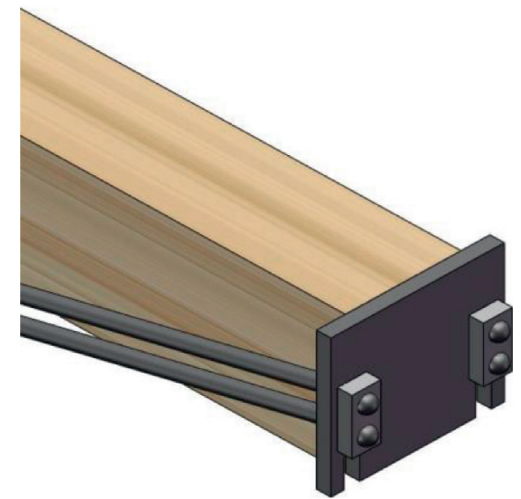

(b)

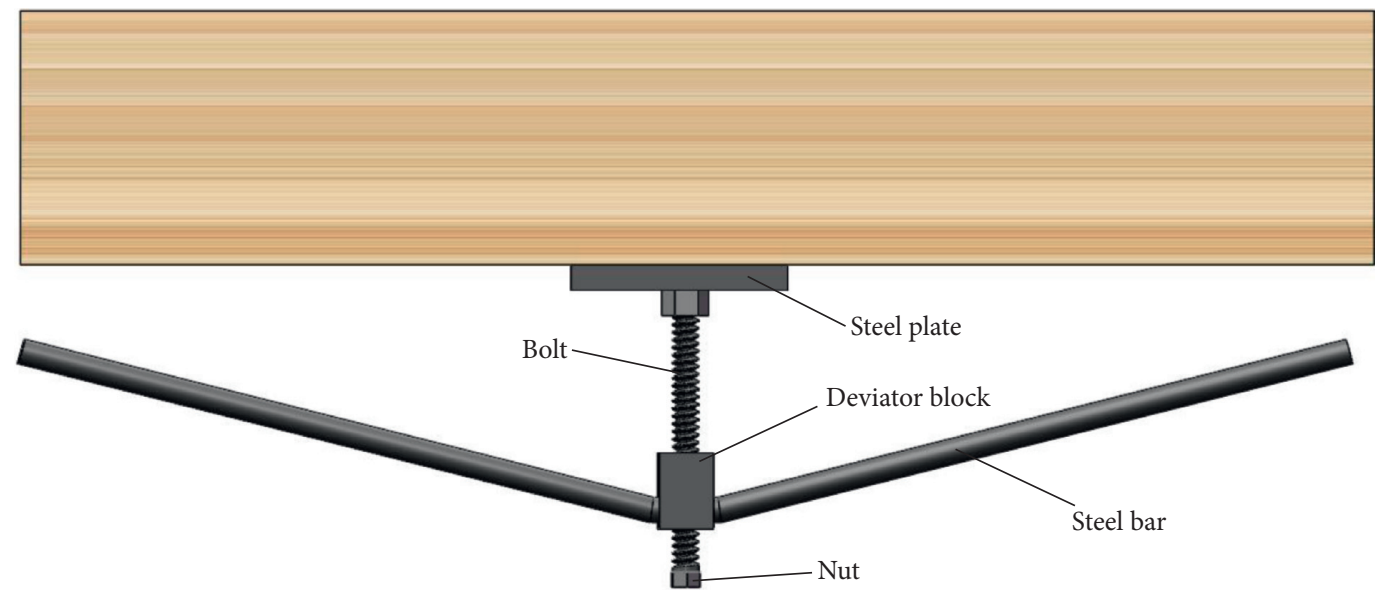

(c)

Figure 2: Steel components. (a) Connection apparatus. (b) Steel plate. (c) Prestressed control device.

were taken as the control group, Group B, which had one working condition and two test beams. In terms of the selection of working conditions, the working condition with four steel bars in each span and a prestress force of $7 \mathrm{kN}$ was chosen from the working conditions of Group A (under this condition, the compressive strength of the material is relatively fully utilized, and the prestress level is relatively suitable). The basic details of the control group are shown in Table 3.
To select the strain of Glulam beams and the steel wires, the $100 \mathrm{~mm} \times 3 \mathrm{~mm}$ strain gauges were pasted at the beam top, the bottom, and the side of the midspan. The $2 \mathrm{~mm} \times 3 \mathrm{~mm}$ strain gauges were pasted to the steel wire surfaces at an $L / 4$ distance from the beams' support points. To monitor the deflection of the beams, three LVDTs (Linear Variable Differential Transformers) with a range of $50 \mathrm{~mm}$ were placed at its support, respectively, and an LVDT with a range of $150 \mathrm{~mm}$ was set in the midspan, as shown in 


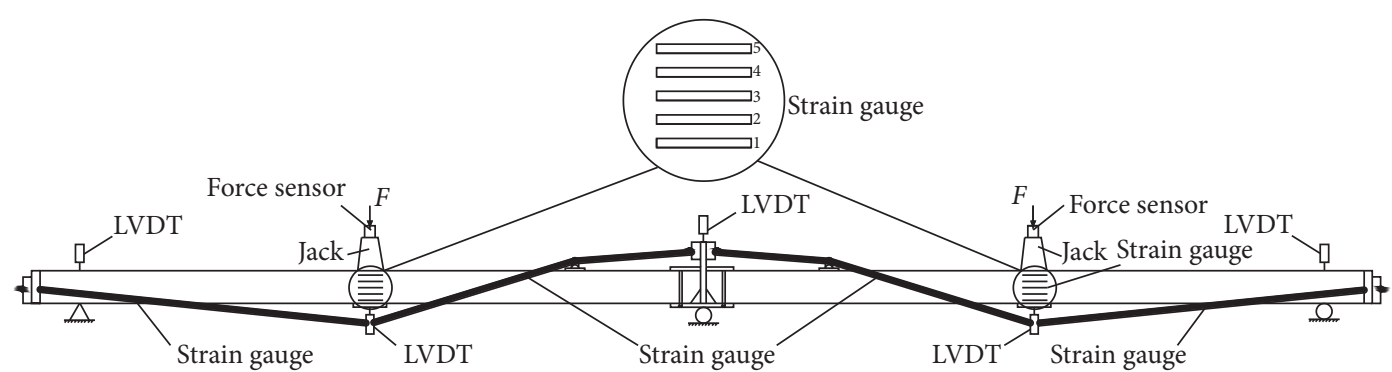

FIGURE 3: Adjustable prestressed continuous Glulam beam.

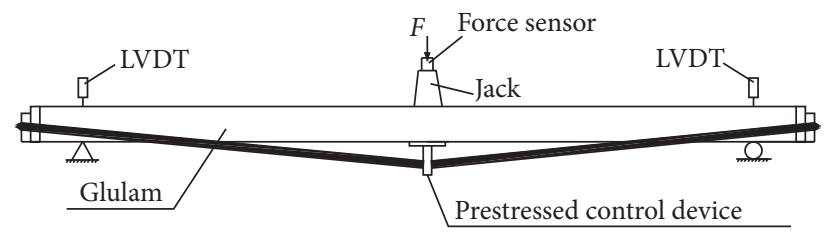

FIgURE 4: Adjustable prestressed simply supported Glulam beam.

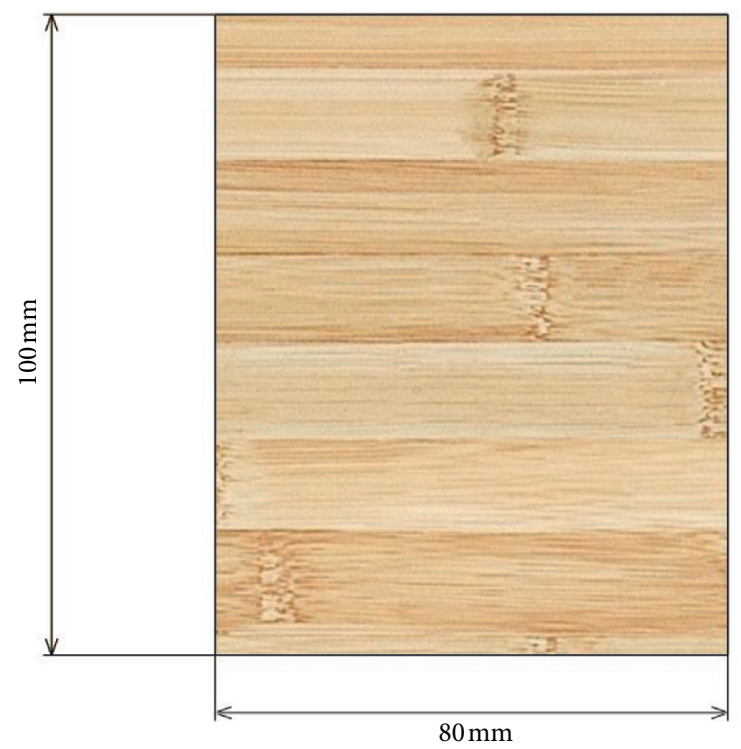

Figure 5: Cross-sectional area.

TABle 1: Basic information of Group I.

\begin{tabular}{|c|c|c|c|c|c|}
\hline $\begin{array}{l}\text { Group (prestressing } \\
\text { force } / \mathrm{kN} \text { ) }\end{array}$ & Beam no. & $\begin{array}{c}\text { Number of } \\
\text { spans }\end{array}$ & $\begin{array}{c}\text { Number of prestressed steel bars in } \\
\text { each span }\end{array}$ & $\begin{array}{c}\text { Reinforcement ratio } \\
(\%)\end{array}$ & $\begin{array}{l}\text { Stress of each steel bar } \\
(\mathrm{MPa})\end{array}$ \\
\hline \multirow{3}{*}{0} & $\mathrm{~L}_{\mathrm{A} 1}$ & 2 & 2 & 0.96 & 0 \\
\hline & $\mathrm{L}_{\mathrm{A} 2}$ & 2 & 4 & 0.96 & 0 \\
\hline & $\mathrm{L}_{\mathrm{A} 3}$ & 2 & 6 & 0.96 & 0 \\
\hline \multirow{3}{*}{7} & $\mathrm{~L}_{\mathrm{A} 4}$ & 2 & 2 & 1.92 & 91.0 \\
\hline & $\mathrm{L}_{\mathrm{A} 5}$ & 2 & 4 & 1.92 & 45.5 \\
\hline & $\mathrm{L}_{\mathrm{A} 6}$ & 2 & 6 & 1.92 & 30.3 \\
\hline \multirow{3}{*}{14} & $\mathrm{~L}_{\mathrm{A} 7}$ & 2 & 2 & 2.38 & 182.0 \\
\hline & $\mathrm{L}_{\mathrm{A} 8}$ & 2 & 4 & 2.38 & 91.0 \\
\hline & $\mathrm{L}_{\mathrm{A} 9}$ & 2 & 6 & 2.38 & 60.6 \\
\hline
\end{tabular}


TABLE 2: Basic information of Group II.

\begin{tabular}{|c|c|c|c|c|c|}
\hline $\begin{array}{l}\text { Group (number of prestressed steel bars } \\
\text { in each span) }\end{array}$ & Beam no. & $\begin{array}{c}\text { Number of } \\
\text { spans }\end{array}$ & $\begin{array}{l}\text { Prestressing force } \\
(\mathrm{kN})\end{array}$ & $\begin{array}{l}\text { Reinforcement ratio } \\
(\%)\end{array}$ & $\begin{array}{l}\text { Stress of each steel bar } \\
(\mathrm{MPa})\end{array}$ \\
\hline \multirow{3}{*}{2} & $\mathrm{~L}_{\mathrm{A} 1}$ & 2 & 0 & 0.96 & 0 \\
\hline & $\mathrm{L}_{\mathrm{A} 4}$ & 2 & 7 & 0.96 & 91.0 \\
\hline & $\mathrm{L}_{\mathrm{A} 7}$ & 2 & 14 & 0.96 & 182.0 \\
\hline \multirow{3}{*}{4} & $\mathrm{~L}_{\mathrm{A} 2}$ & 2 & 0 & 1.92 & 0 \\
\hline & $\mathrm{L}_{\mathrm{A} 5}$ & 2 & 7 & 1.92 & 45.5 \\
\hline & $\mathrm{L}_{\mathrm{A} 8}$ & 2 & 14 & 1.92 & 91.0 \\
\hline \multirow{3}{*}{6} & $\mathrm{~L}_{\mathrm{A} 3}$ & 2 & 0 & 2.38 & 0 \\
\hline & $\mathrm{L}_{\mathrm{A} 6}$ & 2 & 7 & 2.38 & 30.3 \\
\hline & $\mathrm{L}_{\mathrm{A} 9}$ & 2 & 14 & 2.38 & 60.6 \\
\hline
\end{tabular}

TABLE 3: Basic information of the control group.

\begin{tabular}{lcccc}
\hline Beam no. & Number & Prestressing force $(\mathrm{kN})$ & Number of prestressed steel bars & Reinforcement ratio (\%) \\
\hline $\mathrm{L}_{\mathrm{B} 1}$ & 1 & 7 & 4 & \multirow{2}{*}{1.92} \\
$\mathrm{~L}_{\mathrm{B} 2}$ & 1 & & & \\
\hline
\end{tabular}

Figure 3. JM3813 static strain acquisition systems were applied to collect the strain and deflection measurements.

After the prestressed continuous Glulam beams were assembled, turning the nut counterclockwise caused the screw to rotate, as shown in Figure 2(c). Therefore, the steering block moved downward; thus, the reinforcements were stretched, and the prestress was applied to Glulam beams. By adjusting the distance from the deviator block to the bottom of the beam, the value of prestressing can be controlled.

\section{Test Results and Analysis}

3.1. Failure Mode. According to the test results, the failure modes of the prestressed continuous Glulam beams are divided into three types.

3.2. Compressive Failure of the Beam Top. Failure of this type is manifested as follows: initially, with the increase of the load, the deflection increased gradually; when the load reached a certain degree, wrinkling appeared at limber knots, finger joints, and areas with thin wood fibers, because the wood had reached the compressive yield point; then, with the continuous increase of the load, the wrinkling gradually grew downward; finally, when the Glulam was no longer able to resist the compressive force, the beam failed, as shown in Figure 6.

3.3. Tensile Failure of the Beam Bottom. Failure of this type is manifested in two forms: first, with the increase of the load, the deflection increased gradually, the bottom fiber of the Glulam cracked due to insufficient tensile strength, which eventually led to a decrease in the bearing capacity of the beam, and the loading could not be continued anymore; second, with the increase of the load, the deflection increased gradually, wrinkling appeared on top of the Glulam and then extended downward as the load increased continuously, and, finally, the bottom of the Glulam cracked due to tensile force.
Regardless of whether wrinkling appeared on top of the Glulam beam or not, as long as tensile failure appeared at the bottom of the beam, it was regarded as the tensile failure of the beam bottom, as shown in Figure 7.

3.4. Buckling Failure. Failure of this type is manifested as follows: initially, with the increase of the load, the deflection increased gradually, and when the load reached a certain degree, the screw tilted laterally.

There were two phenomena: the first is that wrinkle was produced on one side of the beam initially. With the increase of load, wrinkle extended downward, which led to the failure of the beam's local part and instability of the screw; the other phenomenon is that the joint of the beam and prestressed control device cracked, and, with the increase of the load, the inclination of the screw increased, and the screw was buckling; finally, the beam buckled. The buckling is caused by two factors: one is that the difference in the length of the steel bars had resulted in the different force applied at the two ends of the deviator block, causing the deviator block to drive the screw to deviate out of the plane; another reason is the defects at the contact part between the Glulam and the steel supporting plate at the bottom of the beam along the width direction of the beam; the Glulam could not uniformly resist the force applied by the screw to the Glulam; when the local compressive failure occurred to the Glulam, the screw deviated laterally. Then, with the increase of the loading level, the bearing capacity of the beam no longer increased, the screw tilted even harder, and the beam buckled, as shown in Figure 8.

Statistical analysis of the test results suggested that buckling failure mainly occurred to beams with fewer Glulam defects. In the test design process, antibuckling measures such as adding a cambered nut to the root of the screw or setting a lateral caging device to the root of the jack had been adopted. During the loading process, the Glulam part of the continuous beam was in a bending state, it was mostly the compressive force under some working conditions, and the force was uniform across the section. Therefore, despite the antibuckling measures, if there are 


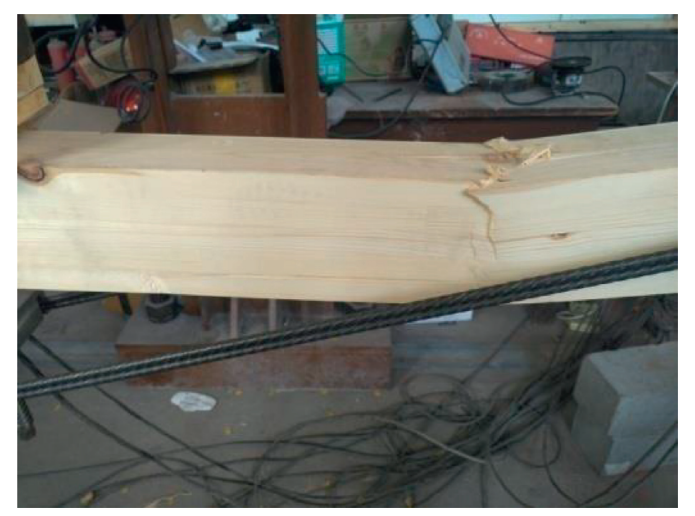

(a)

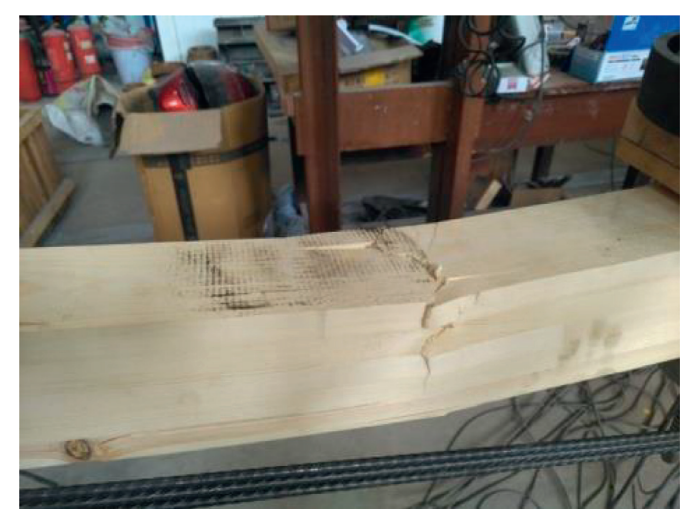

(b)

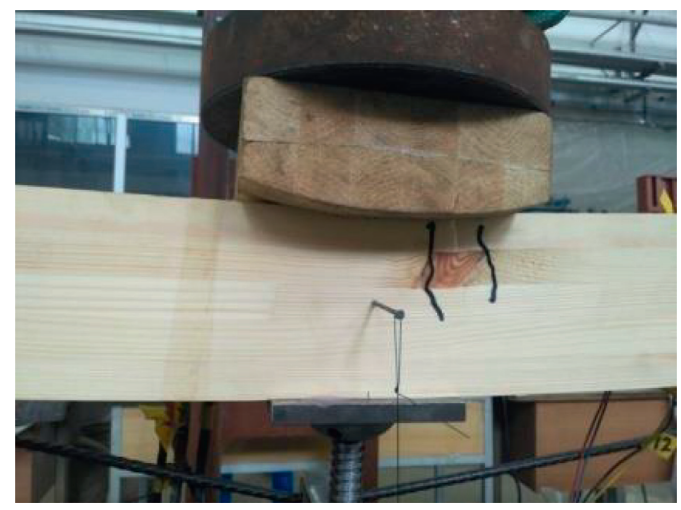

(c)

FIGURE 6: Wrinkling on top of the Glulam beam. (a) Wrinkling on top of the $\mathrm{LA}_{2(2)}$ right span. (b) Wrinkling on top of the LA (2) $_{\text {right span. }}$ (c) Wrinkling on top of the $\mathrm{LA}_{7(1)}$ left span.

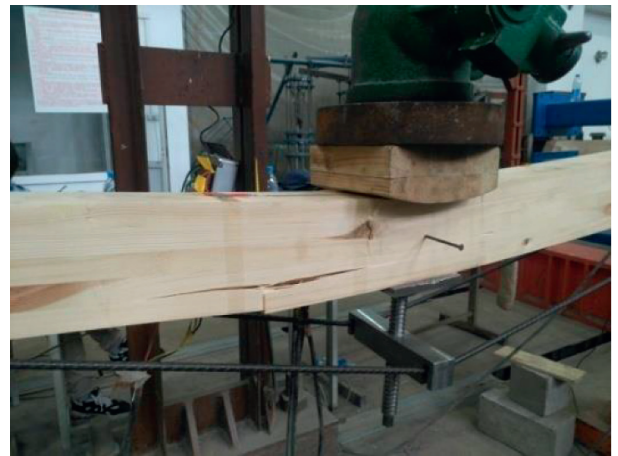

(a)

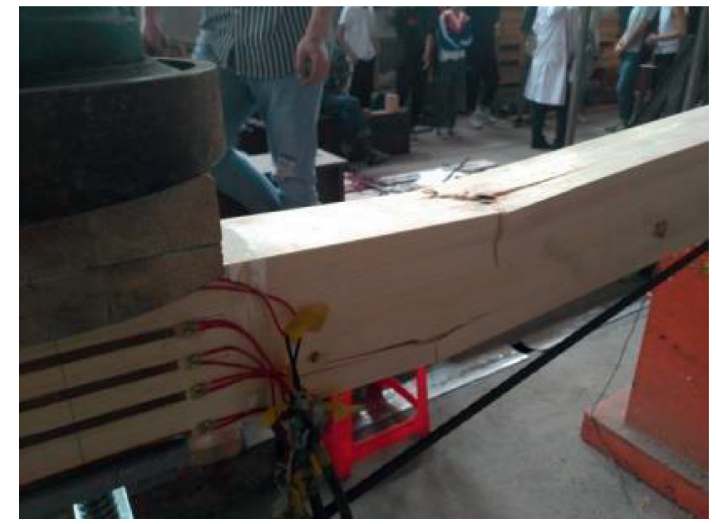

(b)

FIGURE 7: Continued. 


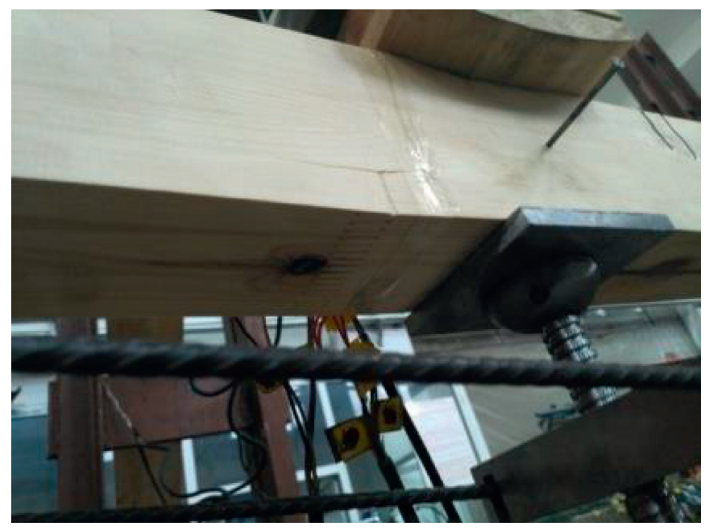

(c)

Figure 7: Cracks at the bottom of the Glulam beam. (a) Cracks at the bottom of the $\mathrm{L}_{\mathrm{A} 1(2)}$ left span. (b) Cracks at the bottom of the $\mathrm{L}_{\mathrm{A} 4(1)}$ left span. (c) Cracks at the bottom of the $\mathrm{L}_{\mathrm{A} 7(2)}$ right span.

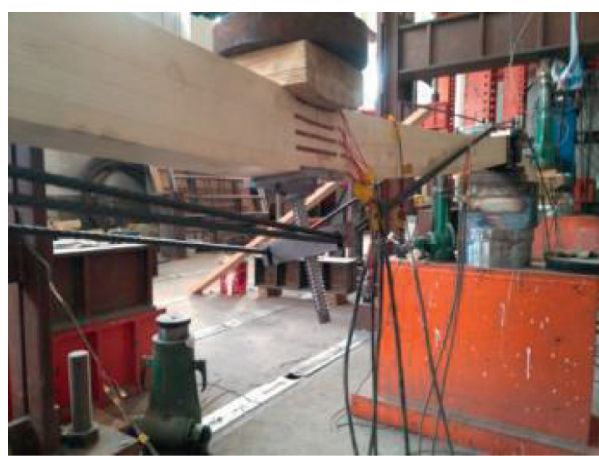

(a)

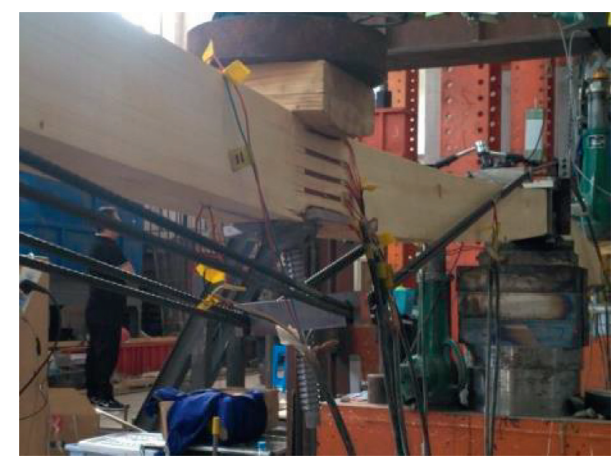

(b)

Figure 8: Buckling failure of the Glulam beam. (a) Buckling failure of the $\mathrm{L}_{\mathrm{A} 2(2)}$ left span. (b) Buckling failure of the $\mathrm{L}_{\mathrm{A} 5(2)}$ left span.

fewer defects with the Glulam, neither beam top compressive failure nor beam bottom tensile failure would occur, but the buckling failure would occur instead.

In many cases, the damage of the two spans of a continuous beam was basically of equal degree. The entire continuous beam can be regarded as failed. However, since the middle support's ability to connect both spans is weak, there also exists a situation where one span is failed and the other span cannot continue the loading; in such case, it is also regarded as the complete continuous beam failure. Generally speaking, except for some individual beams that have suffered a tensile failure, the prestressed continuous Glulam beams demonstrated significant deformation in the early stage of failure, which can be considered a ductile failure. Table 4 shows the failure modes of each continuous beam, and Figure 9 gives the distribution ratio of the failure.

As for the prestressed simply supported beams, the failure of all beams occurred in the middle of the span; the failure is brittle, as shown in Table 4.

It can be seen from Table 4 that when the reinforcement ratio and prestressing force value are relatively small, continuous beams mainly underwent tensile failure at the bottom and compressive failure at the top. Then, with the increase of the reinforcement ratio and the prestress level, the occurrence possibility of buckling failure increased. It is because, in the prestressed continuous Glulam beams, the Glulam part is the compression-flexure member; as the reinforcement ratio and the prestress level increased, the compression force borne by the Glulam increased and, finally, the beams had a buckling failure.

\section{Impact of Reinforcement Ratio}

4.1. Bearing Capacity. When the values of prestressing force are $0 \mathrm{kN}, 7 \mathrm{kN}$, and $14 \mathrm{kN}$, the bearing capacity of the prestressed continuous Glulam beams with different reinforcement ratios is shown in Table 5 .

It can be seen from Table 5 that, given the same prestress level, with the increase of the reinforcement ratio, the bearing capacity of the continuous beams increased correspondingly. Compared with the prestressed continuous Glulam beams with a reinforcement ratio of $1.92 \%$, the bearing capacity of the continuous beams with a reinforcement ratio of $3.84 \%$ increased by $20.30 \%$ to $29.40 \%$; as for continuous beams with a reinforcement ratio of $5.76 \%$, their bearing capacity increased by $30.51 \%$ to $36.36 \%$. 
TABLE 4: Failure modes of simply supported beams and continuous beams.

\begin{tabular}{|c|c|c|c|c|}
\hline Beam no. & Number of steel bars & Reinforcement ratio (\%) & Prestressing force $(\mathrm{kN})$ & Failure mode \\
\hline $\begin{array}{l}\mathrm{L}_{\mathrm{A} 1(1)} \\
\mathrm{L}_{\mathrm{A} 1(2)} \\
\mathrm{L}_{\mathrm{A} 2(1)} \\
\mathrm{L}_{\mathrm{A} 2(2)} \\
\mathrm{L}_{\mathrm{A} 3(1)} \\
\mathrm{L}_{\mathrm{A} 3(2)} \\
\end{array}$ & $\begin{array}{l}4 \\
6\end{array}$ & $\begin{array}{l}3.84 \\
5.76\end{array}$ & 0 & $\begin{array}{c}\mathrm{I}_{\mathrm{L}}, \mathrm{II}_{\mathrm{R}} \\
\mathrm{II}_{\mathrm{L}}, \mathrm{II}_{\mathrm{R}} \\
\mathrm{III}_{\mathrm{L}}, \mathrm{II}_{\mathrm{R}} \\
\mathrm{III}_{\mathrm{L}}, \mathrm{I}_{\mathrm{R}} \\
\mathrm{I}_{\mathrm{L}}, \mathrm{II}_{\mathrm{R}} \\
\mathrm{I}_{\mathrm{L}}, \mathrm{II}_{\mathrm{R}}\end{array}$ \\
\hline $\begin{array}{l}\mathrm{L}_{\mathrm{A} 4(1)} \\
\mathrm{L}_{\mathrm{A} 4(2)} \\
\mathrm{L}_{\mathrm{A} 5(1)} \\
\mathrm{L}_{\mathrm{A} 5(2)} \\
\mathrm{L}_{\mathrm{A6}(1)} \\
\mathrm{L}_{\mathrm{A6}(2)} \\
\end{array}$ & 4 & $\begin{array}{l}3.84 \\
5.76\end{array}$ & 7 & $\begin{array}{c}\mathrm{II}_{\mathrm{L}}, \mathrm{II}_{\mathrm{R}} \\
\mathrm{II}_{\mathrm{L}}, \mathrm{II}_{\mathrm{R}} \\
\mathrm{III}_{\mathrm{L}}, \mathrm{III}_{\mathrm{R}} \\
\mathrm{III}_{\mathrm{L}}, \mathrm{I}_{\mathrm{R}} \\
\mathrm{IV}_{\mathrm{L}}, \mathrm{II}_{\mathrm{R}} \\
\mathrm{II}_{\mathrm{L}}, \mathrm{II}_{\mathrm{R}} \\
\end{array}$ \\
\hline $\begin{array}{l}\mathrm{L}_{\mathrm{A} 7(1)} \\
\mathrm{L}_{\mathrm{A} 7(2)} \\
\mathrm{L}_{\mathrm{A} 8(1)} \\
\mathrm{L}_{\mathrm{A} 8(2)} \\
\mathrm{L}_{\mathrm{A} 9(1)} \\
\mathrm{L}_{\mathrm{A} 9(2)} \\
\end{array}$ & 4 & 3.84 & 14 & $\begin{array}{c}\mathrm{I}_{\mathrm{L}}, \mathrm{II}_{\mathrm{R}} \\
\mathrm{I}_{\mathrm{L}}, \mathrm{II}_{\mathrm{R}} \\
\mathrm{IV}_{\mathrm{L}}, \mathrm{II}_{\mathrm{R}} \\
\mathrm{IV} \mathrm{L}, \mathrm{II}_{\mathrm{R}} \\
\mathrm{III}_{\mathrm{L}}, \mathrm{I}_{\mathrm{R}} \\
\mathrm{IV} \mathrm{V}_{\mathrm{L}}, \mathrm{II}_{\mathrm{R}} \\
\end{array}$ \\
\hline $\begin{array}{l}\mathrm{L}_{\mathrm{B} 1} \\
\mathrm{~L}_{\mathrm{B} 2}\end{array}$ & 4 & 3.84 & 7 & $\begin{array}{l}\text { II } \\
\text { II }\end{array}$ \\
\hline
\end{tabular}

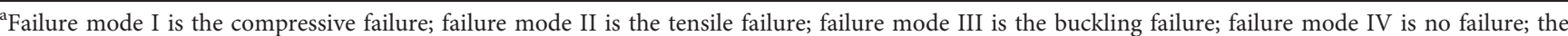
subscript shows the left or the right span; for example, $\mathrm{I}_{\mathrm{L}}$ means the left span has the compressive failure.

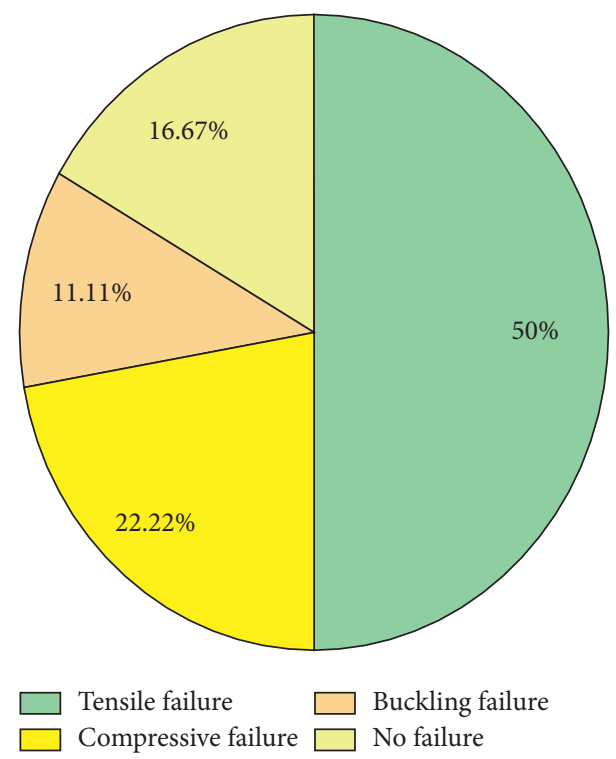

Figure 9: Distribution of failure types of continuous beams.

4.2. Load-Deflection Curve. Under different prestress levels, the shape of the load-deflection curve of each beam is the same; the differences only lie in the magnitude. Figure 10 gives the load-deflection curves under a prestressing force value of $7 \mathrm{kN}$. At the beginning of loading, due to the applied prestress, the beams are arched back, resulting in negative initial deflection. Upward direction is defined as negative, and the opposite direction is positive.

It can be seen from Figure 7 that the defects in the left and right spans of continuous beams are slightly different, and the load-deflection curves are not absolutely coincident, but the difference is insignificant. When the prestress level is the same, with the increase of the reinforcement ratio, the slope and peak value of the load-deflection curve both increase, meaning that the stiffness and bearing capacity of the beam are enhanced. This is because the greater the reinforcement ratio, the greater the tensile force borne by the steel bar and the greater the compressive force borne by the Glulam. The force couple formed by the two forces resisted the bending together, hence stronger bending resistance. In addition, as the reinforcement ratio increased, the maximum deflection of the beam was reduced; that is, the deformation 
TABLE 5: Summary of different steel bar quantity and ultimate bearing capacity of prestressed beams.

\begin{tabular}{|c|c|c|c|c|c|c|}
\hline \multirow{3}{*}{ Group prestressing force $(\mathrm{kN})$} & \multirow{3}{*}{ Beam no. } & \multirow{3}{*}{ Reinforcement ratio (\%) } & \multicolumn{4}{|c|}{ Bearing capacity $(\mathrm{kN})$} \\
\hline & & & \multicolumn{2}{|c|}{ Test value $(\mathrm{kN})$} & \multirow{2}{*}{ Average $(\mathrm{kN})$} & \multirow{2}{*}{ Improvement rate $(\%)$} \\
\hline & & & Left span & Right span & & \\
\hline \multirow{6}{*}{0} & $\mathrm{~L}_{\mathrm{A} 1(1)}$ & \multirow{2}{*}{0.96} & 72.85 & 63.03 & \multirow{2}{*}{61.33} & \multirow{2}{*}{-} \\
\hline & $\mathrm{L}_{\mathrm{Al}(2)}$ & & 59.62 & 61.96 & & \\
\hline & $\mathrm{L}_{\mathrm{A} 2(1)}$ & \multirow{2}{*}{1.92} & 82.47 & 90.35 & \multirow{2}{*}{79.36} & \multirow{2}{*}{29.4} \\
\hline & $\mathrm{L}_{\mathrm{A} 2(2)}$ & & 78.97 & 76.25 & & \\
\hline & $\mathrm{L}_{\mathrm{A} 3(1)}$ & \multirow{2}{*}{2.88} & 86.75 & 85.1 & \multirow{2}{*}{81.45} & \multirow{2}{*}{32.81} \\
\hline & $\mathrm{L}_{\mathrm{A} 3(2)}$ & & 90.15 & 77.8 & & \\
\hline \multirow{6}{*}{7} & $\mathrm{~L}_{\mathrm{A} 4(1)}$ & \multirow{2}{*}{0.96} & 66.53 & 71.39 & \multirow{2}{*}{67.55} & \multirow{2}{*}{-} \\
\hline & $\mathrm{L}_{\mathrm{A} 4(2)}$ & & 71.39 & 68.57 & & \\
\hline & $\mathrm{L}_{\mathrm{A} 5(1)}$ & \multirow{2}{*}{1.92} & 88.99 & 87.53 & \multirow{2}{*}{81.26} & \multirow{2}{*}{20.3} \\
\hline & $\mathrm{L}_{\mathrm{A} 5(2)}$ & & 78.87 & 74.99 & & \\
\hline & $\mathrm{L}_{\mathrm{A} 6(1)}$ & \multirow{2}{*}{2.88} & 95.21 & 94.92 & \multirow{2}{*}{88.16} & \multirow{2}{*}{30.5} \\
\hline & $\mathrm{L}_{\mathrm{A} 6(2)}$ & & 81.4 & 82.96 & & \\
\hline \multirow{6}{*}{14} & $\mathrm{~L}_{\mathrm{A} 7(1)}$ & \multirow{2}{*}{0.96} & 66.82 & 66.82 & \multirow{2}{*}{67.65} & \multirow{2}{*}{-} \\
\hline & $\mathrm{L}_{\mathrm{A} 7(2)}$ & & 68.96 & 68.47 & & \\
\hline & $\mathrm{L}_{\mathrm{A} 8(1)}$ & \multirow{2}{*}{1.92} & 88.01 & 87.62 & \multirow{2}{*}{84.51} & \multirow{2}{*}{24.92} \\
\hline & $\mathrm{L}_{\mathrm{A} 8(2)}$ & & 84.03 & 81.4 & & \\
\hline & $\mathrm{L}_{\mathrm{A} 9(1)}$ & \multirow{2}{*}{2.88} & 97.74 & 98.22 & & \\
\hline & $\mathrm{L}_{\mathrm{A} 9(2)}$ & & 86.75 & 88.11 & 92.25 & 36.36 \\
\hline
\end{tabular}

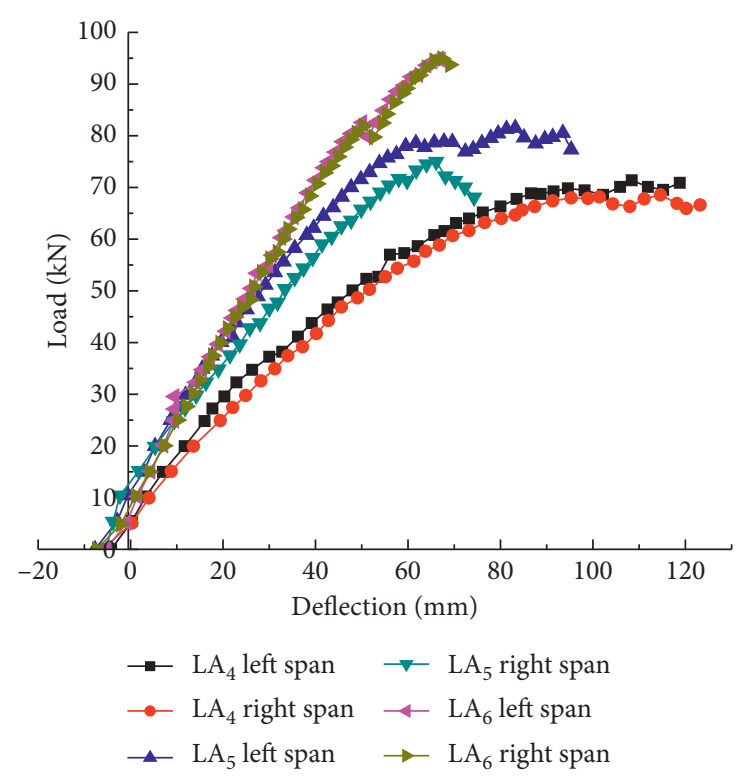

FIgURE 10: Load-deflection curves of beams with different numbers of steel bars under a load of $7 \mathrm{kN}$.

capacity is reduced, but it can still meet the design and service requirements.

4.3. Load-Strain Curve. The load-strain curves of the beams with reinforcement ratios of $1.92 \%, 3.84 \%$, and $5.76 \%$ under the prestressing force of $7 \mathrm{kN}$ are presented, as shown in Figure 11. The serial number of the strain gauge is shown in Figure 3.

From Figure 8, it can be seen that as the bearing capacity increased, the strain of the Glulam plates and the steel bars gradually increased as well; the greater the reinforcement ratio, the smaller the strain at the same position of the
Glulam under the same load; namely, the curves of the beam became closer to each other, indicating that the increase in the reinforcement ratio can reduce the strain of the Glulam, and the force borne by each layer of the Glulam is more evenly distributed; thus, the strength of the material is more fully utilized.

\section{Impact of Prestress}

5.1. Bearing Capacity. When the reinforcement ratio is $1.92 \%, 3.84 \%$, and $5.76 \%$, the bearing capacity of prestressed continuous Glulam beams under different prestress values is shown in Table 6. 


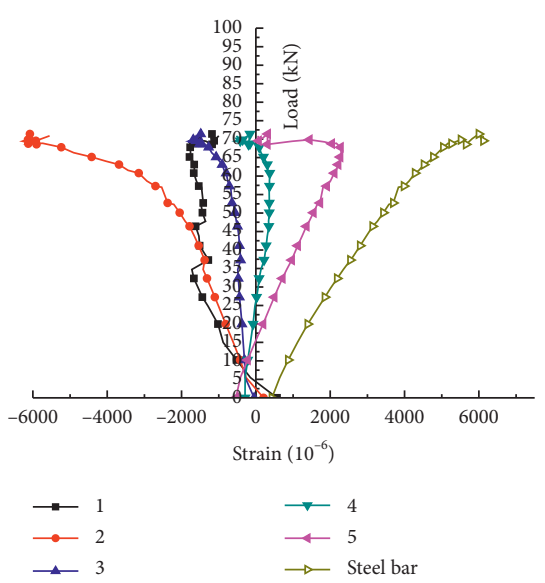

(a)

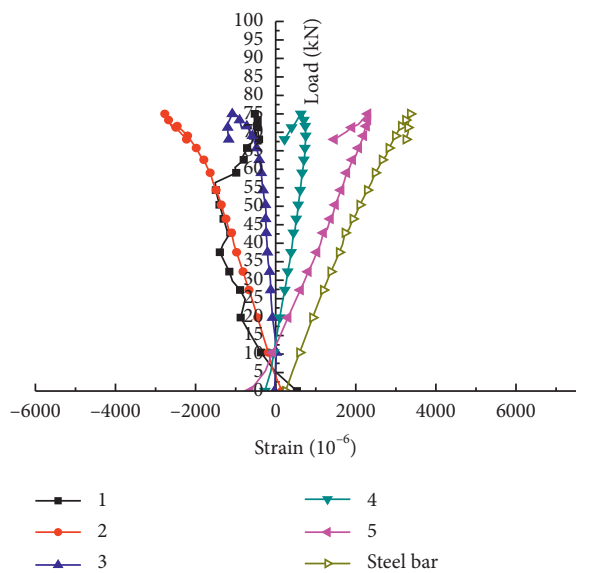

(d)

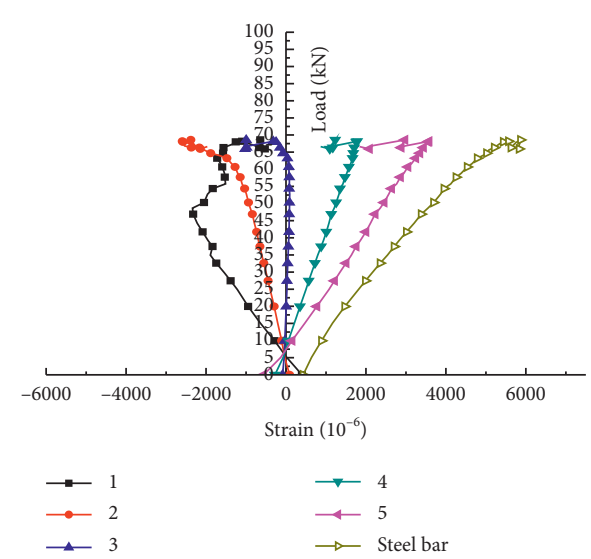

(b)

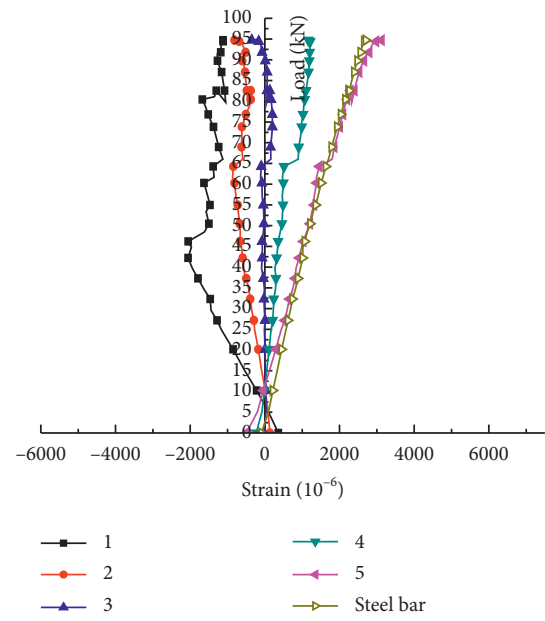

(e)
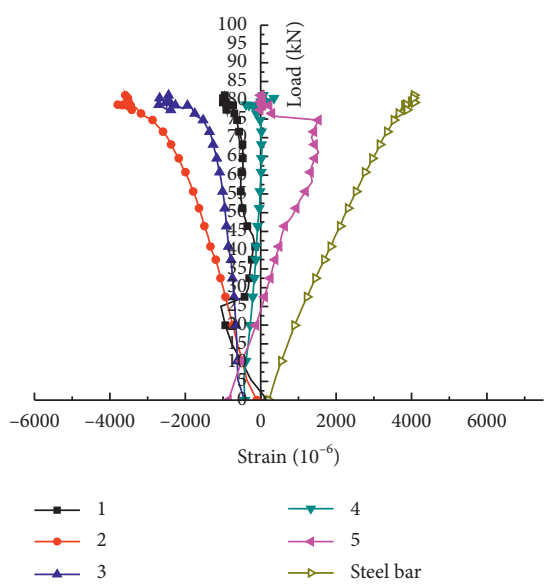

(c)

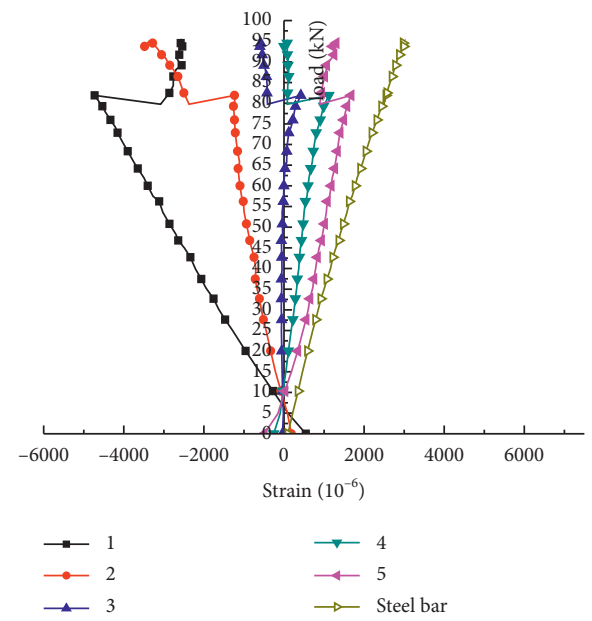

(f)

FiguRE 11: Load-strain curves of beams with different numbers of steel bars. (a) Load-strain curves of the $\mathrm{L}_{\mathrm{A} 4(2)}$ left span. (b) Load-strain curves of the $\mathrm{L}_{\mathrm{A} 4(2)}$ right span. (c) Load-strain curves of the $\mathrm{L}_{\mathrm{A} 5(2)}$ left span. (d) Load-strain curves of the $\mathrm{L}_{\mathrm{A} 5(2)}$ right span. (e) Load-strain curves of the $\mathrm{L}_{\mathrm{A} 6(1)}$ left span. (f) Load-strain curves of the $\mathrm{L}_{\mathrm{A} 6(1)}$ right span.

It can be seen from Table 6 that, given the same reinforcement ratio, the bearing capacity of the continuous beam increased with the increase of the prestress. Compared with the prestressed continuous Glulam beams with a prestressing force of $0 \mathrm{kN}$, the bearing capacity of continuous beams with a prestressing force of $7 \mathrm{kN}$ is increased by $2.39 \%-10.14 \%$; as for continuous beams with a prestressing force of $14 \mathrm{kN}$, the bearing capacity is increased by $6.49 \%-$ $13.26 \%$. The more significant the prestress applied to the beam, the greater the increase of the bearing capacity.

5.2. Load-Deflection Curve. Under different reinforcement ratios, the shape of the load-deflection curve of each beam is the same; the differences only lie in the magnitude. For brevity reason, the load-deflection curves of beams with a reinforcement ratio of $3.84 \%$ are given only, as shown in Figure 12.

It can be seen from Figure 13 that the defects in the left and right spans of continuous beams are slightly different; the load-deflection curves are not entirely coincident. When the reinforcement ratio is the same, with the increase of the prestress, the slope of the load-deflection curves did not change significantly, but the bearing capacity of the beams increased. It can be concluded that the increase of the prestress has an insignificant impact on the stiffness of the beam, but it significantly improved the bearing capacity of the beam.

5.3. Load-Strain Curve. Load-strain curves of beams with a reinforcement ratio of $1.92 \%$ under the prestressing forces of $0 \mathrm{kN}, 7 \mathrm{kN}$, and $14 \mathrm{kN}$ are presented, as shown in Figure 13. The serial number of the strain gauge is shown in Figure 3.

It can be seen from Figure 14 that, at the initial stage of loading, the prestress caused arching back and corresponding reversed stress in each Glulam layer. As the load increased, the arching gradually decreased. The greater the prestress, the larger the peak compressive strain of the Glulam top, and the number of compression-bearing layers is increased. With the increase of the prestress, the Glulam part subject to compression force is increased. Thus, the compressive performance of the Glulam can be more fully utilized. 
TABLE 6: Bearing capacity of beams with different numbers of steel bars.

\begin{tabular}{|c|c|c|c|c|c|c|}
\hline \multirow{3}{*}{ Group (reinforcement ratio \%) } & \multirow{3}{*}{ Beam no. } & \multirow{3}{*}{ Prestress $(\mathrm{kN})$} & \multicolumn{4}{|c|}{ Bearing capacity $(\mathrm{kN})$} \\
\hline & & & \multicolumn{2}{|c|}{ Test value $(\mathrm{kN})$} & \multirow{2}{*}{ Average $(\mathrm{kN})$} & \multirow{2}{*}{ Improvement rate $(\%)$} \\
\hline & & & Left span & Right span & & \\
\hline \multirow{6}{*}{1.92} & $\mathrm{~L}_{\mathrm{A} 1(1)}$ & \multirow{2}{*}{0} & 72.85 & 63.03 & \multirow{2}{*}{61.33} & \multirow[b]{2}{*}{ - } \\
\hline & $\mathrm{L}_{\mathrm{A} 1(2)}$ & & 59.62 & 61.96 & & \\
\hline & $\mathrm{L}_{\mathrm{A} 4(1)}$ & \multirow{2}{*}{7} & 66.53 & 71.39 & \multirow{2}{*}{67.55} & \multirow{2}{*}{10.14} \\
\hline & $\mathrm{L}_{\mathrm{A} 4(2)}$ & & 71.39 & 68.57 & & \\
\hline & $\mathrm{L}_{\mathrm{A} 7(1)}$ & \multirow{2}{*}{14} & 66.82 & 66.82 & \multirow{2}{*}{67.65} & \multirow{2}{*}{10.3} \\
\hline & $\mathrm{L}_{\mathrm{A} 7(2)}$ & & 68.96 & 68.47 & & \\
\hline \multirow{6}{*}{3.84} & $\mathrm{~L}_{\mathrm{A} 2(1)}$ & \multirow{2}{*}{0} & 82.47 & 90.35 & \multirow{2}{*}{79.36} & \multirow{2}{*}{-} \\
\hline & $\mathrm{L}_{\mathrm{A} 2(2)}$ & & 78.97 & 76.25 & & \\
\hline & $\mathrm{L}_{\mathrm{A} 5(1)}$ & \multirow{2}{*}{7} & 88.99 & 87.53 & \multirow{2}{*}{81.26} & \multirow{2}{*}{2.39} \\
\hline & $\mathrm{L}_{\mathrm{A} 5(2)}$ & & 78.87 & 74.99 & & \\
\hline & $\mathrm{L}_{\mathrm{A} 8(1)}$ & \multirow{2}{*}{14} & 88.01 & 87.62 & \multirow{2}{*}{84.51} & \multirow{2}{*}{6.49} \\
\hline & $\mathrm{L}_{\mathrm{A} 8(2)}$ & & 84.03 & 81.4 & & \\
\hline \multirow{6}{*}{5.76} & $\mathrm{~L}_{\mathrm{A} 3(1)}$ & \multirow{2}{*}{0} & 86.75 & 85.1 & \multirow{2}{*}{81.45} & \multirow{2}{*}{-} \\
\hline & $\mathrm{L}_{\mathrm{A} 3(2)}$ & & 90.15 & 77.8 & & \\
\hline & $\mathrm{L}_{\mathrm{A} 6(1)}$ & \multirow{2}{*}{7} & 95.21 & 94.92 & \multirow{2}{*}{88.16} & \multirow{2}{*}{8.24} \\
\hline & $\mathrm{L}_{\mathrm{A} 6(2)}$ & & 81.4 & 82.96 & & \\
\hline & $\mathrm{L}_{\mathrm{A} 9(1)}$ & \multirow{2}{*}{14} & 97.74 & 98.22 & & \\
\hline & $\mathrm{L}_{\mathrm{A} 9(2)}$ & & 86.75 & 88.11 & 92.25 & 13.26 \\
\hline
\end{tabular}

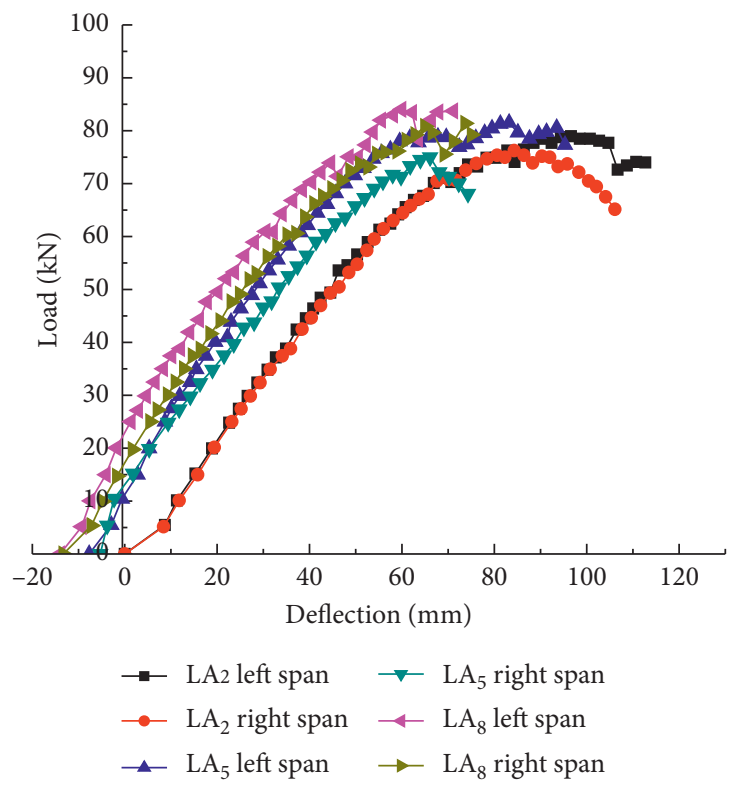

Figure 12: Load-deflection curves of beams with four steel bars.

\section{Contrastive Analysis of Continuous Beams and Simply Supported Beams}

To verify the rationality of the prestressed continuous Glulam beams, this study carried out comparative tests on prestressed simply supported beams of the same type as shown in Table 7. Typical hinged beams are selected and compared with the continuous beams under the same working conditions, and the corresponding load-deflection curves are obtained as shown in Figure 14.

According to comparative analysis results, under the same working condition, compared with simply supported beams, the bearing capacity of the continuous beams is increased by $40 \%$, and the stiffness is increased by $13 \%$. In terms of curve slope, the slope of continuous beams is greater than that of simply supported beams; the stiffness of the beams had been significantly improved. This is because as the structural form changed from simply supported beams to continuous beams, the middle support part can transmit negative bending moment, which greatly reduced the bending moment of the beam at the midspan part. Compared with simply supported beams, the bending moment distribution of the continuous beams at each section of each span is more evenly distributed. By 


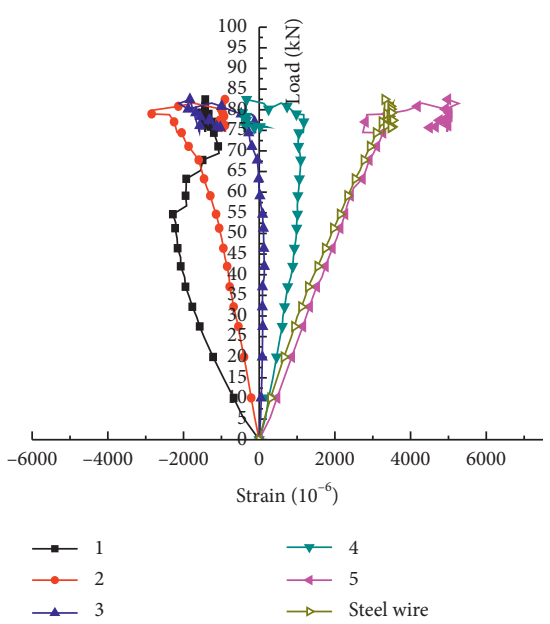

(a)
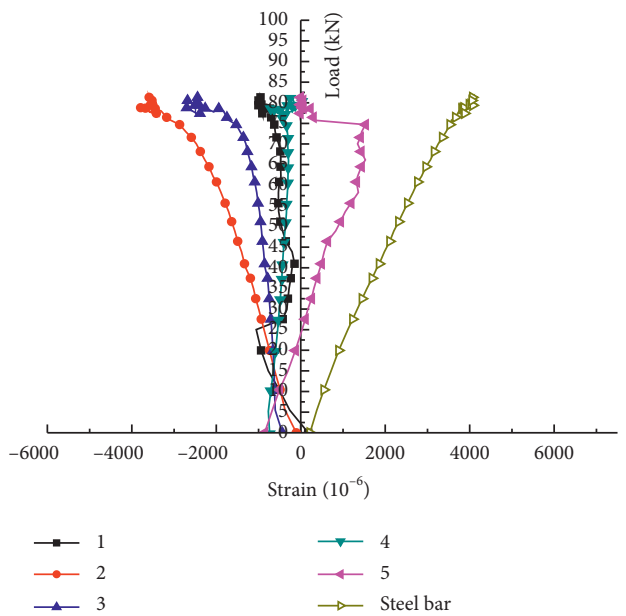

(c)

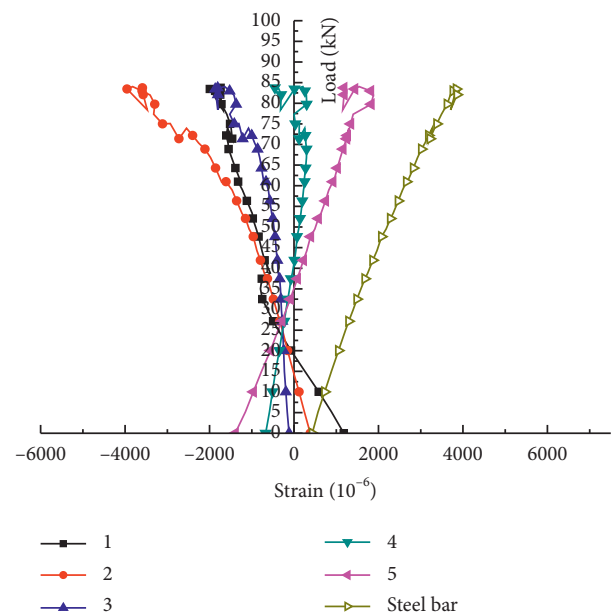

(e)
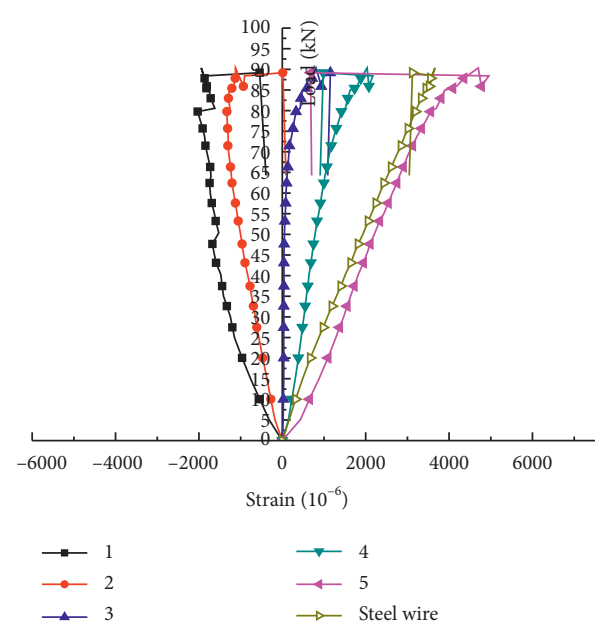

(b)
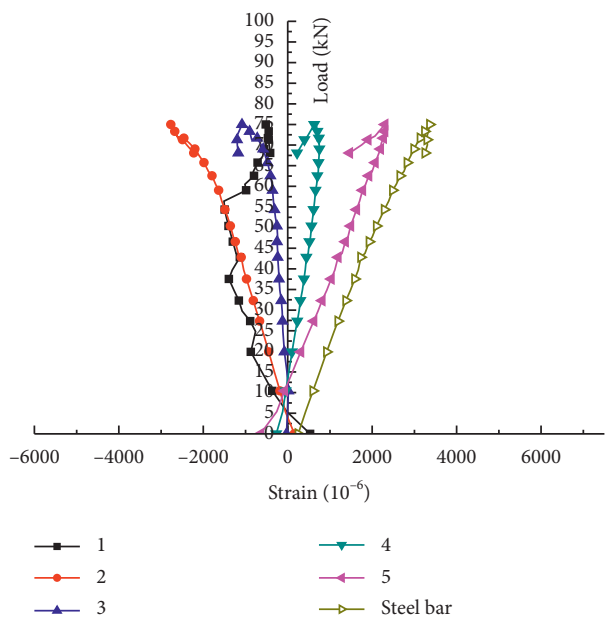

(d)

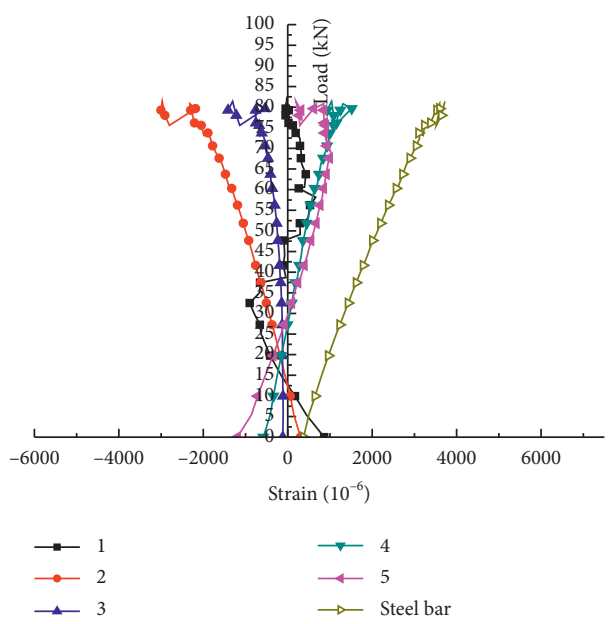

(f)

FIGURE 13: Load-strain curves of beams with six steel bars. (a) Load-strain curves of the $\mathrm{L}_{\mathrm{A} 2(1)}$ left span. (b) Load-strain curves of the $\mathrm{L}_{\mathrm{A} 2(1)}$ right span. (c) Load-strain curves of the $\mathrm{L}_{\mathrm{A} 5(2)}$ left span. (d) Load-strain curves of the $\mathrm{L}_{\mathrm{A} 5(2)}$ right span. (e) Load-strain curves of the $\mathrm{L}_{\mathrm{A} 8(2)}$ left span. (f) Load-strain curves of the $\mathrm{L}_{\mathrm{A} 8(2)}$ right span. 


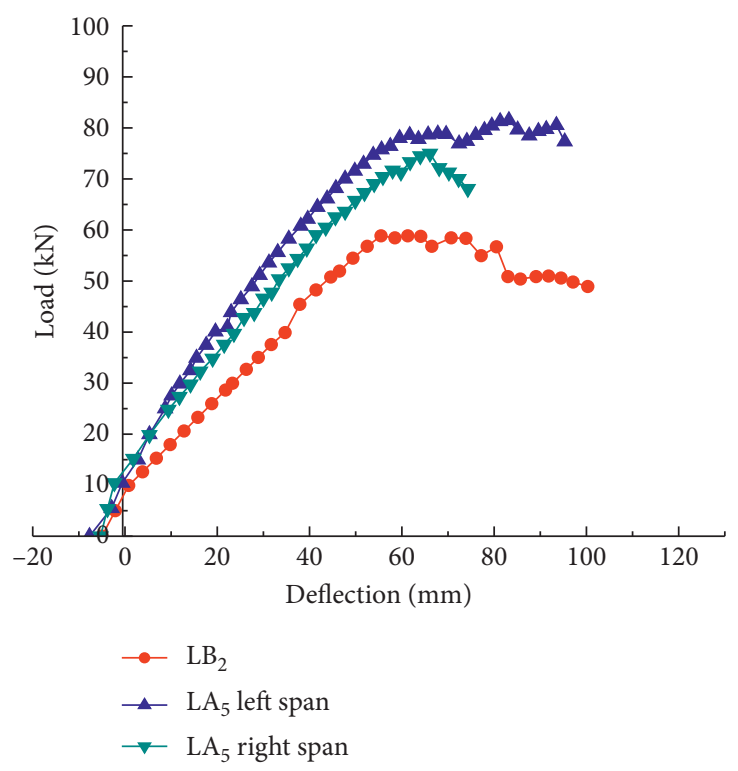

Figure 14: Load-deflection curves of simply supported beams and continuous beams under the same working condition.

TABLE 7: Comparison of bearing capacities of hinged beams and continuous beams under the same working condition.

\begin{tabular}{|c|c|c|c|c|c|c|c|}
\hline \multirow{3}{*}{ Beam no. } & \multirow{3}{*}{ Reinforcement ratio (\%) } & \multirow{3}{*}{ Prestressing force $(\mathrm{kN})$} & \multicolumn{5}{|c|}{ Bearing capacity $(\mathrm{kN})$} \\
\hline & & & \multicolumn{3}{|c|}{ Test value $(\mathrm{kN})$} & \multirow{2}{*}{ Average $(\mathrm{kN})$} & \multirow{2}{*}{ Improvement rate $(\%)$} \\
\hline & & & Left span & Right span & Overall & & \\
\hline $\mathrm{L}_{\mathrm{A} 5(1)}$ & \multirow{2}{*}{3.84} & \multirow{2}{*}{7} & 88.99 & 87.53 & 88.26 & \multirow{2}{*}{82.6} & \multirow{2}{*}{40} \\
\hline $\mathrm{L}_{\mathrm{A} 5(2)}$ & & & 78.87 & 74.99 & 76.93 & & \\
\hline $\mathrm{L}_{\mathrm{B} 1}$ & \multirow{2}{*}{3.84} & \multirow{2}{*}{7} & - & - & 59.64 & \multirow{2}{*}{59} & \multirow{2}{*}{-} \\
\hline $\mathrm{L}_{\mathrm{B} 2}$ & & & - & - & 58.36 & & \\
\hline
\end{tabular}

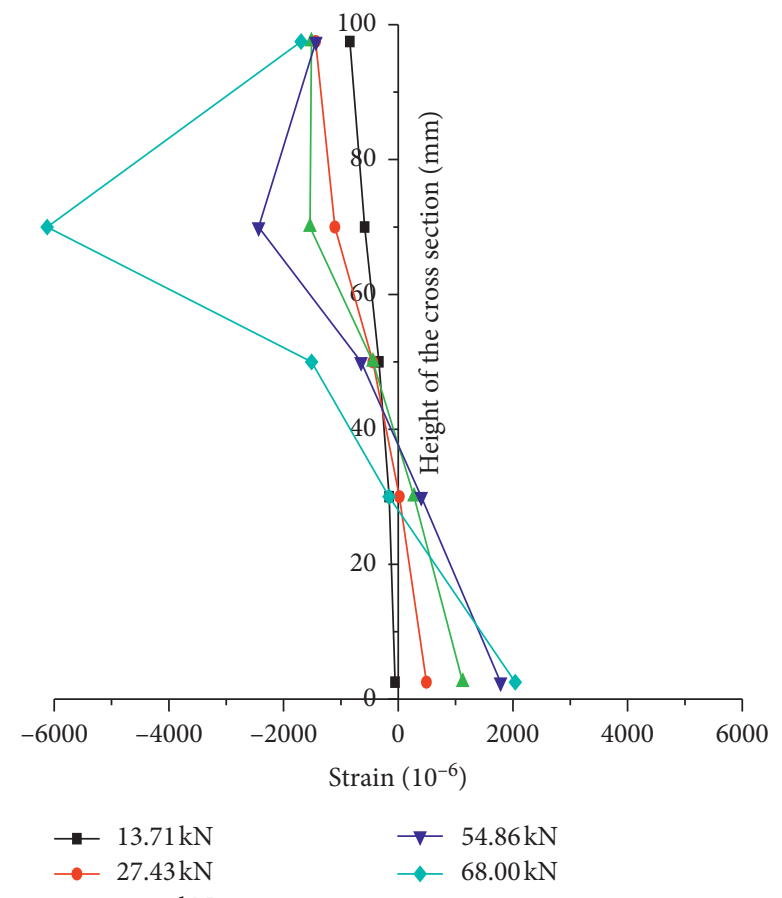

(a)

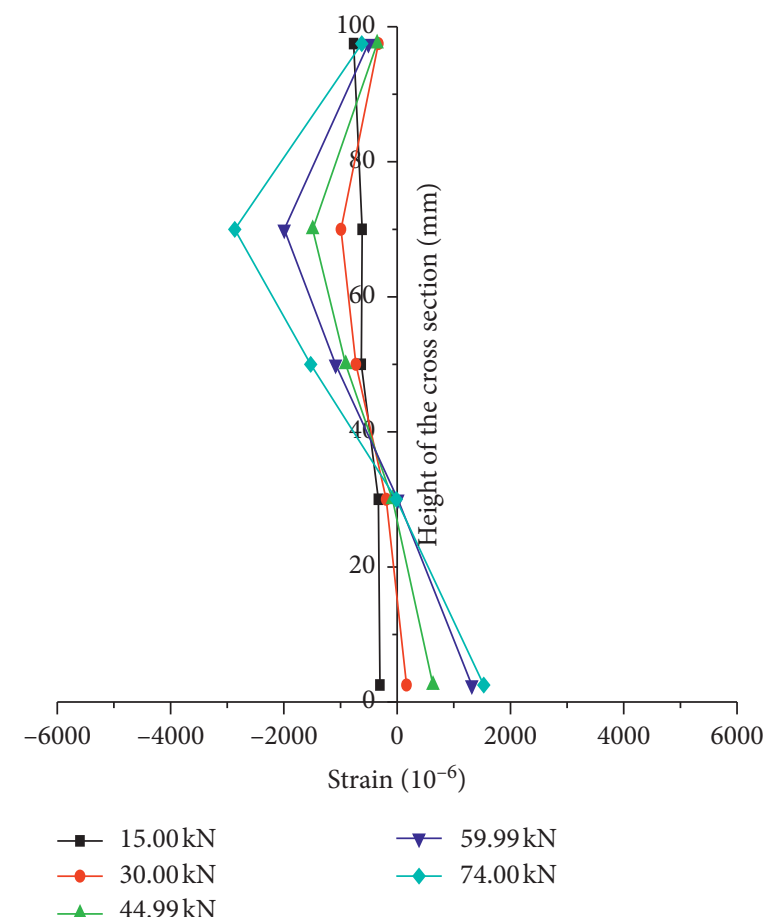

(b)

FIGURE 15: Continued. 


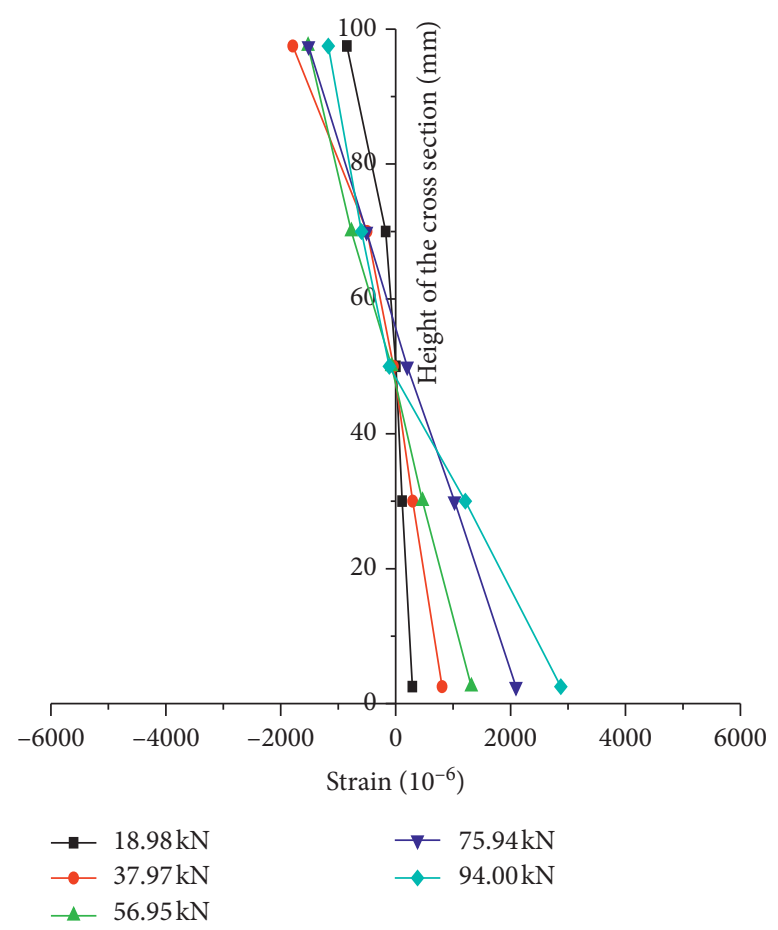

(c)

Figure 15: Section strain curves of beams under a prestressing force of $7 \mathrm{kN}$. (a) Section strain curves of $\mathrm{L}_{\mathrm{A} 4(2)}$. (b) Section strain curves of $\mathrm{L}_{\mathrm{A} 5(2)}$. (c) Section strain curves of $\mathrm{L}_{\mathrm{A6}(1)}$.
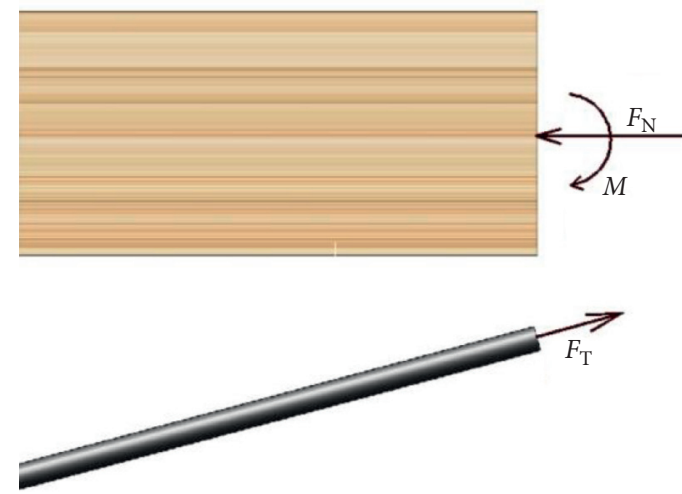

FIGURE 16: Internal force diagram of prestressed continuous Glulam beams.

reasonably arranging the layout of the steel bars in the setup, the stress distribution of the steel bars and Glulam is more reasonable, which can give full play to their respective advantages.

Because of no similar research on other forms of prestressed continuous beams, there is no direct comparison. Nevertheless, based on former research $[28,29,35]$, compared with Glulam beams, the bearing capacity of the continuous prestressed beams can be increased by $106.4 \%$ to $652.4 \%$, and the bearing capacity of other types of prestressed Glulam beams was increased by $28.5 \%$ to $28.8 \%$ $[21,26]$. Therefore, compared with other types of prestressed beams, the prestressed continuous beam proposed is more effective and feasible.

\section{Theoretical Analysis}

To verify the plane section assumption of the Glulam part of the prestressed Glulam beams, the strain along the beam height each span of the continuous Glulam beams is studied. One typical beam is selected from each group to plot the cross-sectional strain curves, as shown in Figure 15. Since the changes of the cross-sectional strain of the beams with different prestressing force values are similar, only the crosssectional strain curves of beams under a prestressing force of $7 \mathrm{kN}$ are given here.

It can be seen from Figure 15 that when the applied prestressing force is the same, with the increase of the number of steel bars, the position of the neutral axis gradually drops. 
In the initial stage of loading, the Glulam part of the beam conformed to the plane section assumption; in the later stage of loading, as the Glulam gradually yielded, bending appeared in the compression area of the load-strain curves. Since certain reliability must be retained in the design, it can be considered that the Glulam part of the beam conformed to the plane section assumption in the bearing capacity state.

Internal force diagram of prestressed continuous Glulam beams is shown in Figure 16; $F_{\mathrm{N}}$ is the axial force of Glulam, $M$ is the bending moment, and $F_{\mathrm{T}}$ is the axial force of steel bars. Since the prestressed steel bars are located outside of Glulam beams proposed in this study, the analytical method cannot be directly employed to solve the bending capacity of the beam. Therefore, in the design stage, the axial force and the bending moment at the ends of the Glulam and tensile force of the steel bar can be obtained, based on the mechanical analysis. Then, Glulam beams can be regarded as a compression-flexure member for design.

\section{Conclusions}

This paper studied the mechanical behavior of prestressed Glulam continuous beams, providing a comparison with prestressed Glulam continuous beams and simply supported beams. The conclusions outlined below are drawn:

(1) There were three main failure types of prestressed Glulam continuous beams: the compressive failure of the beam top, the tensile failure of the beam bottom, and the buckling failure.

(2) Under the same prestress level, as the reinforcement ratio increases, the continuous beams' bearing capacity and stiffness increase. Compared with beams with a reinforcement ratio of $1.92 \%$, the bearing capacity of beams with a reinforcement ratio of $3.84 \%$ is increased by $20.3 \%-29.4 \%$, and the bearing capacity of beams with a reinforcement ratio of $5.76 \%$ is increased by $30.51 \%-36.36 \%$.

(3) For the same reinforcement ratio, as the prestress increases, the bearing capacity of the continuous beams increases. Compared with beams without prestress, the bearing capacity of beams with a prestressing force of $7 \mathrm{kN}$ is increased by $2.39 \%-$ $10.14 \%$; when the prestressing force is $14 \mathrm{kN}$, this value is increased by $6.49 \%-13.26 \%$.

(4) Compared with simply supported beams under the condition of the same reinforcement ratio and the same prestress, since the bending moment of continuous beams is more evenly distributed, its bearing capacity is increased by $40 \%$, and deformation is reduced by $13 \%$. Therefore, the method that composes prestressed continuous Glulam beams is effective, safe, and reliable.

\section{Data Availability}

The data used to support the findings of this study are included within the article.

\section{Conflicts of Interest}

The authors declare that they have no conflicts of interest to report regarding the present study.

\section{Acknowledgments}

The authors thank Prof. Hongliang Zuo and Prof. Jianmin Zhang for participating in the purchase of wood and other experimental equipment for this study. This paper was supported by the Natural Science Foundation of Heilongjiang Province (Grant nos. LH2019E005 and LH2020E009) and the Natural Science Foundation of Fujian Province (Grant no. 2020J01402).

\section{References}

[1] J. Kohler and S. Svensson, "Probabilistic representation of duration of load effects in timber structures," Engineering Structures, vol. 33, no. 2, pp. 462-467, 2011.

[2] M. J. He, J. L. Chen, and H. Q. Liu, "The development prospect of wood-frame housing in rural China," Architectural Technology, vol. 40, pp. 940-942, 2009.

[3] C. Y. Du and C. H. Yu, "Green, space, construction-interpretation of modern western timber structure," New Architecture, vol. 5, pp. 17-21, 2005.

[4] C. M. Fan and S. L. Chen, "Recent development of science and technology in timber structures," Harbin Institute of Technology, vol. 36, no. 6, pp. 812-814, 2004.

[5] X. Y. Zhou, L. Cao, D. Zeng et al., "Flexural capacity analysis of glulam beams," Building Structure, vol. 45, no. 22, pp. 91-96, 2008.

[6] C. A. Issa and Z. Kmeid, "Advanced wood engineering: glulam beams," Construction and Building Materials, vol. 19, no. 2, pp. 99-106, 2005.

[7] A. S. Gribanov, S. I. Roshchina, M. V. Popova, and M. S. Sergeev, "Laminar polymer composites for wooden structures," Magazine of Civil Engineering, vol. 83, no. 7, pp. 3-11, 2018.

[8] H. Z. Zhang, H. T. Li, I. Corbi, and C. Ottavia, "AFRP influence on parallel bamboo strand lumber beams," Sensors, vol. 18, no. 9, Article ID 2854, 2018.

[9] H. L. Zuo, H. R. Liu, and J. X. Lu, "Effect of new self-tapping screw reinforcement measures on bending performance of glulam beams," Journal of Northeast Forestry University, vol. 48, no. 5, pp. 112-116+121, 2020.

[10] H. Zuo, Y. Qiu, D. Fu, and N. Guo, "Bending performance test on the different forms of reinforced glulam beams," Journal of Northeast Forestry University, vol. 47, no. 8, pp. 62-65, 2019.

[11] G. Fava, V. Carvelli, and C. Poggi, "Pull-out strength of gluedin FRP plates bonded in glulam," Construction and Building Materials, vol. 43, pp. 362-371, 2013.

[12] G. M. Raftery and P. D. Rodd, "FRP reinforcement of lowgrade glulam timber bonded with wood adhesive," Construction and Building Materials, vol. 91, pp. 116-125, 2015.

[13] V. D. Luca and C. Marano, "Prestressed Glulam timbers reinforced with steel bars," Construction and Building Materials, vol. 30, pp. 206-217, 2011.

[14] B. Anshari, Z. W. Guan, A. Kitamor, and K. Jung, "Structural behavior of glued laminated timber beams pre-stressed by compressed wood," Construction and Building Materials, vol. 29, pp. 24-32, 2011. 
[15] B. K. Shi, W. Q. Liu, and H. F. Yang, "Experimental investigation on the long-term behavior of prefabricated timberconcrete composite beams with steel plate connections," Construction and Building Materials, vol. 266, no. Part A, Article ID 120892, 2021.

[16] H. Yang, D. Ju, W. Liu, and W. Lu, "Prestressed glulam beams reinforced with CFRP bars," Construction and Building Materials, vol. 109, pp. 73-83, 2016.

[17] T. Nowak, J. Jasieńko, E. Kotwica, and S. Krzosek, "Strength enhancement of timber beams using steel plates-review and experimental tests," Drewno, vol. 59, no. 196, pp. 75-90, 2016.

[18] S. José, J. Marco, J. Branco, M. Vítor, and C. F. Cunha, "Bond between glulam and NSM CFRP laminates," Construction and Building Materials, vol. 40, pp. 260-269, 2013.

[19] J. M. Branco, M. P. Jorge, and J. S. Cruz, Double Span Continuous Glulam Slabs Strengthened with GFRP, Springer, Berlin, Germany, 2014.

[20] J. Zhang, H. Shen, R. G. Qiu et al., "Short-Term flexural behavior of prestressed glulam beams reinforced with curved tendons," Journal of Structural Engineering, vol. 146, no. 6, Article ID 04020086, 2020.

[21] Y. Wei, S. C. Yan, K. Zhao et al., "Experimental and theoretical investigation of steel-reinforced bamboo scrimber beams," Engineering Structures, vol. 223, Article ID 111179, 2020.

[22] Z. W. Guan, P. D. Rodd, and D. J. Pope, "Study of glulam beams pre-stressed with pultruded GRP," Computers \& Structures, vol. 83, pp. 2476-2487, 2005.

[23] E. McConnell, D. McPolin, and S. Taylor, "Post-tensioning of glulam timber with steel tendons," Construction and Building Materials, vol. 73, pp. 426-433, 2014.

[24] J. H. Negrao, "Preliminary study on wire prestressing methods for timber pieces reinforcement," Construction and Building Materials, vol. 102, pp. 1093-1100, 2014.

[25] M. Khelifa and A. Celzard, "Numerical analysis of flexural strengthening of timber beams reinforced with CFRP strips," Composite Structures, vol. 111, pp. 393-400, 2014.

[26] H. F. Yang, W. X. Zhu, J. D. Hao, and W. Xu, "Experimental study on the flexural behaviors of external prestressed glulam beams," Journal of Nanjing Tech University, vol. 38, no. 5, pp. 68-73+93, 2016.

[27] G. M. Raftery and A. M. Harte, "Low-grade glued laminated timber reinforced with FRP plate," Composites Part B: Engineering, vol. 42, no. 4, pp. 724-735, 2011.

[28] N. Guo, Y. J. Wang, and H. L. Zuo, "Study of short-term flexural behavior for glue-bamboo and lumber beams under different pre-stressed state," Civil Engineering Journal, vol. 2, 2017.

[29] N. Guo, W. B. Wang, and H. L. Zuo, "Flexural property of string beam of pre-stressed glulam based on influence of regulation and control," Structural Durability \& Health Monitoring, vol. 13, pp. 143-179, 2019.

[30] J. M. Zhang, J. L. Pan, and H. B. Dong, "Experimental research on deformation characteristic of timber beam string structure using ANSYS FEM," Low Temperature Architecture Technology, vol. 2, pp. 49-51, 2006.

[31] H. R. Valipour and K. Crews, "Efficient finite element modelling of timber beams strengthened with bonded fibre reinforced polymers," Construction and Building Materials, vol. 25, no. 8, pp. 3291-3300, 2011.

[32] China National Standard, Standard for Design of Timber Structures (GB50005-2017), China National Standard, Beijing, China, 2017.
[33] China National Standard, Method of Testing in Compressive Strength Parallel to Grain of wood (GB/T 1935-2009), China National Standard, Beijing, China, 2009.

[34] W. J. Wang, H. L. Zuo, N. Guo et al., "The mechanical property tests for structural glubam of the tensile strength parallel to grain," Low Temperature Architecture Technology, vol. 4, pp. 38-40, 2015.

[35] T. T. Zhao, Study of Short-Time Flexural Behavior for Glulam String Beams in Different Prestressed State, Northeast Forestry University, Heilongjiang, China, 2015. 